\title{
M-Zn (M = Sb, V, and Nb) Substituted Strontium Hexaferrites with Enhanced Saturation Magnetization for Permanent Magnet Applications
}

\author{
Nina Sapoletova, Sergey Kushnir, Kyunghan Ahn, Sung Yong An*, Moonhee Choi, \\ Jae Yeong Kim, Changhak Choi, and Sungkwon Wi \\ Corporate R\&D Institute, Samsung Electro-Mechanics, Gyeonggi-do 16674, Korea
}

(Received 25 May 2016, Received in final form 18 July 2016, Accepted 19 July 2016)

\begin{abstract}
M-Zn (M = Sb, V, Nb) substituted $M$-type strontium hexaferrites were prepared by a ceramic method. The phase composition, morphology and magnetic properties were studied by x-ray diffractometry, scanning electron microscopy and vibrating sample magnetometry. Saturation magnetization increases with a substitution up to $75.0 \mathrm{emu} / \mathrm{g}(2.5 \%$ higher compared to unsubstituted hexaferrite) and then decreases with a further substitution. A coercive field of substituted hexaferrite powders with highest saturation magnetization is more than 3 kOe. Substituted strontium hexaferrite powders prepared in this work are a rare example of high $M_{S}$ compositions without doping rare-earth elements and would be a promising candidate for a permanent magnet application.
\end{abstract}

Keywords : strontium hexaferrite, substitution saturation magnetization, zinc, antimony, magnetic properties

\section{Introduction}

$M$-type hexaferrites with a chemical formula $\mathrm{AFe}_{12} \mathrm{O}_{19}$ $(\mathrm{A}=\mathrm{Sr}, \mathrm{Ba})$ are hard magnetic materials which have been widely used for motor components [1]. Saturation magnetization $\left(M_{\mathrm{S}}\right)$ of a hard magnetic material is one of the most important magnetic properties for improving efficiency and energy saving of motors. Saturation magnetization should be affected by occupancy of iron positions in hexaferrite structure. In the $M$-type hexaferrite crystal structure $\mathrm{Fe}^{3+}$ ions are in five different oxygen sites where two of these (tetrahedral $-4 f_{1}$ and octahedral $-4 \mathrm{f}_{2}$ ) are down-spin sites and 3 (octahedral $2 \mathrm{a}$ and $12 \mathrm{k}$, trigonal bipyramid $-2 \mathrm{~b}$ ) are up-spin sites. Substitution of iron in down-spin sites $\left(4 \mathrm{f}_{1}\right.$ and $\left.4 \mathrm{f}_{2}\right)$ by non-magnetic element leads to the increase in $M_{\mathrm{S}}$. Based upon this direction much work has been done for enhancing $M_{\mathrm{S}}$ [2]. Unfortunately only few successful results have been achieved [3-8]. It has been reported that a preferred $\mathrm{Zn}^{2+}$ substitution for tetrahedral $4 \mathrm{f}_{1}$ iron positions in magnetoplumbite structure can lead to the increase in saturation magnetization [4].

CThe Korean Magnetics Society. All rights reserved.

*Corresponding author: Tel: $+82-31-210-3017$

Fax: +82-31-300-7900, e-mail: sung.an@samsung.com
Here we report on the increase in $M_{\mathrm{S}}$ for $\mathrm{M}-\mathrm{Zn}(\mathrm{M}=$ $\mathrm{Sb}, \mathrm{V}$, and $\mathrm{Nb}$ ) substituted strontium hexaferrites with ratio $M: Z n=1: 1$. Prior to this work several works including Nb-Zn [7-9], V-Zn [10] and Sb-Zn [10] substituted $M$-type hexaferrites with $\mathrm{M}: \mathrm{Zn}=1: 2$ has been investigated. To the best our knowledge study of M-Zn $(\mathrm{M}=\mathrm{Sb}, \mathrm{Nb}$, and $\mathrm{V})$ substituted hexaferrites with ratio $\mathrm{M}$ $: \mathrm{Zn}=1: 1$ has not been conducted. Substituted hexaferrites were prepared by a ceramic method. Phase and element composition, morphology and magnetic properties of samples were studied using different characterization techniques.

\section{Experiment}

Following chemicals were used for synthesis of samples: $\mathrm{SrCO}_{3}$ (JPC, $99.9 \%$ ), $\mathrm{Fe}_{2} \mathrm{O}_{3}$ (JPC, $99.9 \%$ ), $\mathrm{ZnO}$ (JPC, $99.9 \%$ ), $\mathrm{Sb}_{2} \mathrm{O}_{5}$ (Aldrich, $99.995 \%$ ), $\mathrm{V}_{2} \mathrm{O}_{5}$ (JPC, $99.99 \%$ ) $\mathrm{Nb}_{2} \mathrm{O}_{5}$ (Aldrich, $99.99 \%$ ). Hexaferrite powders were prepared by a ceramic method from $\mathrm{SrCO}_{3}, \mathrm{Fe}_{2} \mathrm{O}_{3}, \mathrm{ZnO}$ and $\mathrm{M}_{2} \mathrm{O}_{5}\left(\mathrm{Sb}_{2} \mathrm{O}_{5}, \mathrm{~V}_{2} \mathrm{O}_{5}\right.$ or $\left.\mathrm{Nb}_{2} \mathrm{O}_{5}\right)$. Precursors were mixed with $\mathrm{ZrO}_{2}$ balls in ethanol for 18 hours. The mixed powders were calcined at $T=1,255{ }^{\circ} \mathrm{C}$ for $4 \mathrm{~h}$ after drying them. The calcined powders of $\operatorname{SrFe}_{12-\mathrm{x}} \mathrm{M}_{\mathrm{x}} \mathrm{O}_{19}(\mathrm{M}$ $=\mathrm{Sb}, \mathrm{V}$, and $\mathrm{Nb}$ ) were crushed using a mortar for magnetic and XRD measurements. The chemical compositions 
of Sb-Zn substituted hexaferrite powders were confirmed using inductively coupled plasma atomic emission spectroscopy (ICP-AES) (table S1 in Supporting Information).

The phase analysis of the powders was performed by X-ray diffraction using a Philips X'Pert PRO diffractometer with $\mathrm{CuK} \alpha$ radiation. Lattice constants were calculated using MAUD program [11]. A vibrating sample magnetometer (VSM) Quantum Design Model 6000 was used to measure magnetic properties at room temperature with a maximum applied field of $50 \mathrm{kOe}$. Saturation magnetization was assumed to be taken as a magnetization at the magnetic field of $50 \mathrm{kOe}$. Element analysis was performed using ICP-AES on Shimadzu ICPS-8100 spectrometer. Scanning electron microscopy (SEM) images were registered using Nova NanoSEM 450 (FEI).

\section{Results and Discussion}

Based upon a XRD analysis all samples should be in a single $\mathrm{SrFe}_{12} \mathrm{O}_{19}$ phase. XRD patterns are shown on a figure S1 (Supporting Information). All samples except for the sample with nominal composition $\mathrm{SrFe}_{11.8} \mathrm{~V}_{0.1} \mathrm{Zn}_{0.1} \mathrm{O}_{19}$ contain also a little amount of impurity phases (see Table 1) increasing with substitution amount $x$. $\mathrm{Zn}$ tends to mainly substitutes $\mathrm{Fe}$ in the hexaferrite lattice because of no $\mathrm{Zn}$-based phases for powders with $\mathrm{M}: \mathrm{Zn}=1: 1$. Impurity phases are $\mathrm{Sr}_{2} \mathrm{FeSbO}_{6}, \mathrm{SrFe}_{0.5} \mathrm{Nb}_{0.5} \mathrm{O}_{3}$, and $\mathrm{Sr}_{3} \mathrm{~V}_{2} \mathrm{O}_{8}$ in $\mathrm{Sb}, \mathrm{Nb}$ and $\mathrm{V}$ substituted samples, respectively. Thus, a ratio $\mathrm{M}: \mathrm{Zn}<1: 1$ should be maintained for a single phase in the hexaferrite structure and the average oxidation state of the $\mathrm{M}$ ion should be more than $4+$ in order to satisfy the electro-neutrality of the samples. $\mathrm{Sb}, \mathrm{Nb}$ and $\mathrm{V}$ elements in impurity phases have $5+$ oxidation states. It has been known that $\mathrm{Sb}_{2} \mathrm{O}_{5}$ transforms into $\alpha-\mathrm{Sb}_{2} \mathrm{O}_{4}$ at $T$ $=525^{\circ} \mathrm{C}[12,13]$ and thus it may be possible that $\mathrm{Sb}$

(a)

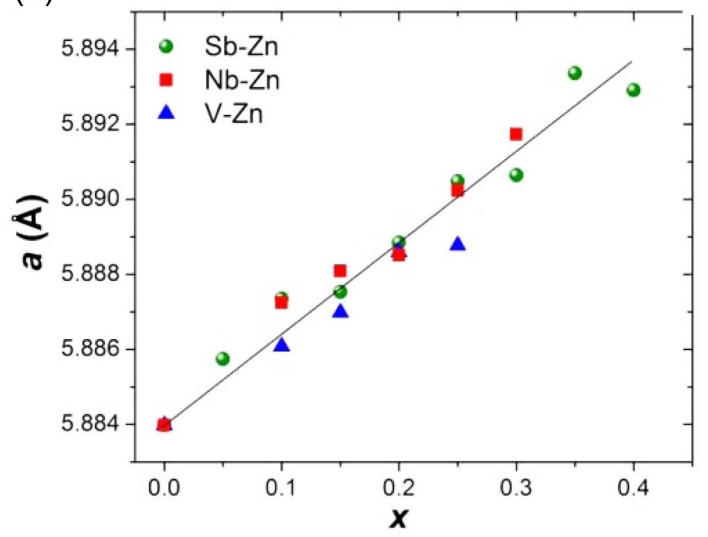

could have a mixed $(3+$ and $5+)$ oxidation state in the hexaferrite structure. This assumption is in agreement with Brahma et al's works $[14,15]$, where the coexistence of $\mathrm{Sb}^{3+}$ and $\mathrm{Sb}^{5+}$ in $\mathrm{Sb}_{2} \mathrm{O}_{3}$-doped $M$-type hexaferrites were shown by a chemical analysis.

Figure 1 shows the effect of the substitution amount $x$ calculated from the XRD data on lattice constants. A lattice constant $a$ increases with increasing $x$ for all substituted samples (Fig. 1a). And the lattice constant $c$ simultaneously increases with increasing $x$ for $\mathrm{Sb}-\mathrm{Zn}$ and $\mathrm{Nb}-\mathrm{Zn}$ substituted hexaferrites, but decreases with increasing $x$ for V-Zn substituted hexaferrite powders (Fig. 1b). It could be explained that mean crystal radii (for all oxidation states and VI coordination number) of $\mathrm{Sb}$ and $\mathrm{Nb}$ ions are larger than the radius of $\mathrm{Fe}^{3+}$ ion and the mean crystal radius of $\mathrm{V}$ ions is smaller (Table 2, [16]). Nearly linear changes of lattice constants with $x$ verify that hexaferrite compositions changes corresponding to substitution.

Dependences of saturation magnetization and coercive force obtained from hysteresis loops for samples with nominal composition $\mathrm{SrFe}_{12-2 \mathrm{x}} \mathrm{Sb}_{\mathrm{x}} \mathrm{Zn}_{\mathrm{x}} \mathrm{O}_{19}$ obtained are shown in Fig. 2a. Both saturation magnetization $(M \mathrm{~s})$ and coercive field $(H \mathrm{c})$ increase with increasing $x$ reach maxima at $x=0.2\left(75.0 \mathrm{emu} / \mathrm{g}\right.$ for $M_{\mathrm{S}}$ and $3.0 \mathrm{kOe}$ for $H_{\mathrm{C}}$ ), and then decrease with increasing $\mathrm{x}$. The increase in $M_{\mathrm{S}}$ presumably relates with $\mathrm{Zn}^{2+}$ occupation in the downspin tetrahedral positions of $\mathrm{Fe}^{3+}\left(4 \mathrm{f}_{1}\right)$ as similar as $\mathrm{La}-\mathrm{Zn}$ substituted strontium hexaferrite in previous works $[6$, 17]. Antimony in mixed $(3+$ and $5+)$ oxidation state may provide an appropriate crystal radius to facilitate the occupation of $\mathrm{Zn}^{+2}$ in the $4 \mathrm{f}_{1}$ positions and thus relax a hexaferrite structure distortion. The decrease in $M_{\mathrm{S}}$ with $x>0.2$ should be probably due to the occupancy of $\mathrm{Zn}^{2+}$ in the up-spin positions of $\mathrm{Fe}^{3+}$ or/and due to the increase

(b)

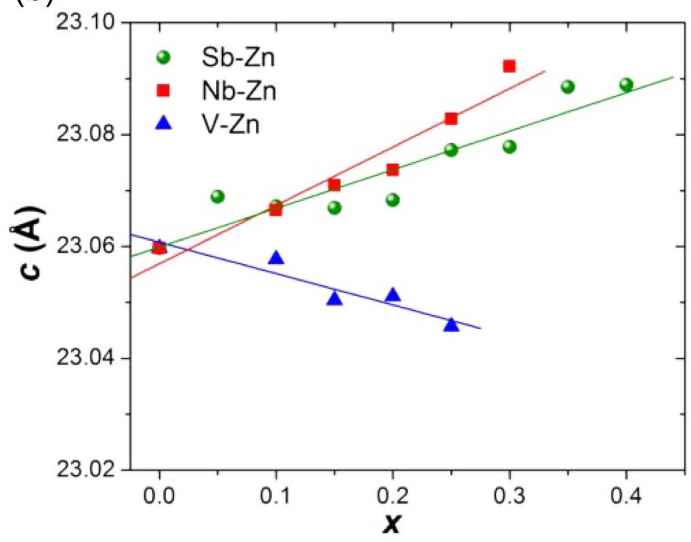

Fig. 1. (Color online) Dependences of lattice constants: (a) $a$ and (b) $c$ from the substitution amount $x$ for Sb-Zn (circles), Nb-Zn (squares) and $\mathrm{V}-\mathrm{Zn}$ (triangles) substituted strontium hexaferrites with $\mathrm{M}: \mathrm{Zn}=1: 1$. 
Table 1. Phase composition of samples according XRD data.

\begin{tabular}{|c|c|c|c|c|c|}
\hline Nominal composition & $\bar{x}$ & Phases & "Nominal composition & $\mathrm{x}$ & Phases \\
\hline $\mathrm{SrFe}_{12} \mathrm{O}_{19}$ & - & $\mathrm{SrFe}_{12} \mathrm{O}_{19}$ & \multirow{9}{*}{$\mathrm{SrFe}_{11.6} \mathrm{Sb}_{0.4-\mathrm{x}} \mathrm{Zn}_{\mathrm{x}} \mathrm{O}_{19}$} & 0 & \multirow{7}{*}{$\mathrm{SrFe}_{12} \mathrm{O}_{19}, \mathrm{Sr}_{2} \mathrm{FeSbO}_{6}$} \\
\hline \multirow{8}{*}{$\mathrm{SrFe}_{12-2 \mathrm{x}} \mathrm{Sb}_{\mathrm{x}} \mathrm{Zn}_{\mathrm{x}} \mathrm{O}_{19}$} & 0.05 & \multirow{8}{*}{$\mathrm{SrFe}_{12} \mathrm{O}_{19}, \mathrm{Sr}_{2} \mathrm{FeSbO}_{6}$} & & 0.1 & \\
\hline & 0.1 & & & 0.13 & \\
\hline & 0.15 & & & 0.17 & \\
\hline & 0.2 & & & 0.2 & \\
\hline & 0.25 & & & 0.23 & \\
\hline & 0.3 & & & 0.27 & \\
\hline & 0.35 & & & 0.3 & $\mathrm{SrFe}_{12} \mathrm{O}_{19}, \mathrm{ZnFe}_{2} \mathrm{O}_{4}$ \\
\hline & 0.4 & & & 0.4 & $\mathrm{SrFe}_{12} \mathrm{O}_{19}, \mathrm{Sr}_{2} \mathrm{Zn}_{2} \mathrm{Fe}_{28} \mathrm{O}_{46}$ \\
\hline \multirow{5}{*}{$\mathrm{SrFe}_{12-2 \mathrm{x}} \mathrm{Nb}_{\mathrm{x}} \mathrm{Zn}_{\mathrm{x}} \mathrm{O}_{19}$} & 0.1 & \multirow{5}{*}{$\mathrm{SrFe}_{12} \mathrm{O}_{19}, \mathrm{SrFe}_{0.5} \mathrm{Nb}_{0.5} \mathrm{O}_{3}$} & \multirow{5}{*}{$\mathrm{SrFe}_{12-2 \mathrm{x}} \mathrm{V}_{\mathrm{x}} \mathrm{Zn}_{\mathrm{x}} \mathrm{O}_{19}$} & 0.1 & $\mathrm{SrFe}_{12} \mathrm{O}_{19}$ \\
\hline & 0.15 & & & 0.15 & \\
\hline & 0.2 & & & 0.2 & $\mathrm{SrFe}_{12} \mathrm{U}_{19}, \mathrm{Sr}_{3} \mathrm{v}_{2} \mathrm{U}_{8}$ \\
\hline & 0.25 & & & 0.25 & $\mathrm{SrFe}_{12} \mathrm{O}_{19}, \mathrm{Sr}_{3} \mathrm{~V}_{2} \mathrm{O}_{8}$ \\
\hline & 0.3 & & & 0.3 & $\alpha-\mathrm{Fe}_{2} \mathrm{O}_{3}$ \\
\hline \multirow[t]{2}{*}{$\mathrm{SrFe}_{12-3 \mathrm{x}} \mathrm{Nb}_{\mathrm{x}} \mathrm{Zn}_{2 \mathrm{x}} \mathrm{O}_{19}$} & 0.15 & $\begin{array}{c}\mathrm{SrFe}_{12} \mathrm{O}_{19}, \mathrm{SrFe}_{0.5} \mathrm{Nb}_{0.5} \mathrm{O}_{3}, \mathrm{ZnFe}_{2} \mathrm{O}_{4}, \\
\mathrm{Sr}_{2} \mathrm{Zn}_{2} \mathrm{Fe}_{28} \mathrm{O}_{46}\end{array}$ & & & \\
\hline & 0.25 & $\mathrm{SrFe}_{12} \mathrm{O}_{19}, \mathrm{SrFe}_{0.5} \mathrm{Nb}_{0.5} \mathrm{O}_{3}, \mathrm{ZnFe}_{2} \mathrm{O}_{4}$ & & & \\
\hline
\end{tabular}

Table 2. $\mathrm{Fe}^{3+}$ positions in $M$-type hexaferrite structure and crystal radii of $\mathrm{Fe}, \mathrm{Zn}, \mathrm{Sb}, \mathrm{Nb}$, and $\mathrm{V}$ ions $(\AA)$ for different coordination numbers [16].

\begin{tabular}{|c|c|c|c|c|c|c|c|c|c|c|c|c|}
\hline \multicolumn{2}{|c|}{$\begin{array}{c}\mathrm{Fe}^{3+} \text { in } M \text {-type } \\
\text { hexaferrite structure }\end{array}$} & \multirow{2}{*}{$\begin{array}{l}\text { Coordination } \\
\text { numbers }\end{array}$} & \multicolumn{10}{|c|}{ Crystal ionic radius, $\AA$} \\
\hline Position & Spin direction & & $\mathrm{Fe}^{3+}$ & $\mathrm{Zn}^{2+}$ & $\mathrm{Sb}^{3+}$ & $\mathrm{Sb}^{5+}$ & $\mathrm{Nb}^{3+}$ & $\mathrm{Nb}^{4+}$ & $\mathrm{Nb}^{5+}$ & $\mathrm{V}^{3+}$ & $\mathrm{V}^{4+}$ & $\mathrm{V}^{5+}$ \\
\hline $4 f_{1}$ & $\downarrow$ & IV & 0.63 & 0.74 & 0.90 & - & - & - & 0.62 & - & - & 0.495 \\
\hline $4 f_{2}$ & $\downarrow$ & VI & & & & & & & & & & \\
\hline $12 \mathrm{k}$ & $\uparrow$ & VI & 0.785 & 0.88 & 0.90 & 0.74 & 0.86 & 0.82 & 0.78 & 0.78 & 0.72 & 0.68 \\
\hline $2 \mathrm{a}$ & $\uparrow$ & VI & & & & & & & & & & \\
\hline $2 b$ & $\uparrow$ & $\mathrm{V}$ & 0.72 & 0.82 & 0.94 & - & - & - & - & - & 0.67 & 0.60 \\
\hline
\end{tabular}

in the impurity phase amount.

Further composition experiments were performed in order to find an optimal ratio $\mathrm{Sb}: \mathrm{Zn}$ for $M_{\mathrm{S}}$ enhancement in $\mathrm{SrFe}_{11.6} \mathrm{Sb}_{0.4-\mathrm{x}} \mathrm{Zn}_{\mathrm{x}} \mathrm{O}_{19}$ samples. The maximum of $M_{\mathrm{S}}$ was observed for the sample with $x=0.2(\mathrm{Sb}: \mathrm{Zn}$ ratio $=$ $1: 1$, Fig. 2b). The increase of $M_{\mathrm{S}}$ for the sample with $x=$ 0.4 (only $\mathrm{Zn}$-contained) may be related with a formation of magnetic $X$-type hexaferrite second phase $\left(\mathrm{Sr}_{2} \mathrm{Zn}_{2} \mathrm{Fe}_{28} \mathrm{O}_{46}\right.$, $M_{\mathrm{S}}=79.4 \mathrm{emu} / \mathrm{g}$, [18]). Coercive field almost does not change until $x \leq 0.2$, but decreases with increasing $x(x>$ $0.2)$.

For $\mathrm{Nb}-\mathrm{Zn}$ substituted samples saturation magnetization increases with increasing $x$ up to value $74.7 \mathrm{emu} / \mathrm{g}$ (for $x$ $=0.2, H_{\mathrm{C}}=3.2 \mathrm{kOe}$, Fig. 3a). It is plausible that the increase in $M_{\mathrm{S}}$ could be related with the same reasoning as in the case of $\mathrm{Sb}-\mathrm{Zn}$ substituted hexaferrites: the $\mathrm{Zn}^{2+}$ occupancy in $4 f_{1}$ iron positions and the coexistence of mixed $(3+, 4+$, and $5+)$ oxidation states in $\mathrm{Nb}$. Coercive field decreases with increasing $x$ for $x \geq 0.1$ (from 3.7 to $2.8 \mathrm{kOe})$. Also, $\mathrm{SrFe}_{12-3 \mathrm{x}} \mathrm{Nb}_{\mathrm{x}} \mathrm{Zn}_{2 \mathrm{x}} \mathrm{O}_{19}$ with $x=0.15$ and $x=0.25$ was prepared in order to be compared to an optimal ratio $\mathrm{Nb}: \mathrm{Zn}=1: 1$. Both saturation magnetization (72.1-72.8 emu/g) and coercive field (2.1-2.4 kOe) for these samples (table S2 in Supporting Information) are lower than for samples with $\mathrm{Nb}: \mathrm{Zn}=1: 1 \quad\left(M_{\mathrm{S}}=74.4\right.$ $74.7 \mathrm{emu} / \mathrm{g}$ and $H_{\mathrm{C}}=2.8-3.4 \mathrm{kOe}$ for $\left.x=0.15-0.3\right)$ due to the larger amount of the impurity phases in unequal $\mathrm{Nb}: \mathrm{Zn}$ ratio samples (see Fig. S1c, d in Supporting Information).

$\mathrm{V}-\mathrm{Zn}$ substituted samples show a maximum of $M_{\mathrm{S}}$ observed for $x=0.15$ (74.8 emu/g, Fig. 3b) and maximum of $H_{\mathrm{C}}$ for $x=0.15-0.25(3.4-3.6 \mathrm{kOe}) . \mathrm{V}-\mathrm{Zn}$ substituted strontium hexaferrites reveal the enhancement in $M_{\mathrm{S}}$ as same reasoning as for $\mathrm{Sb}-\mathrm{Zn}$ and $\mathrm{Nb}-\mathrm{Zn}$ substituted 

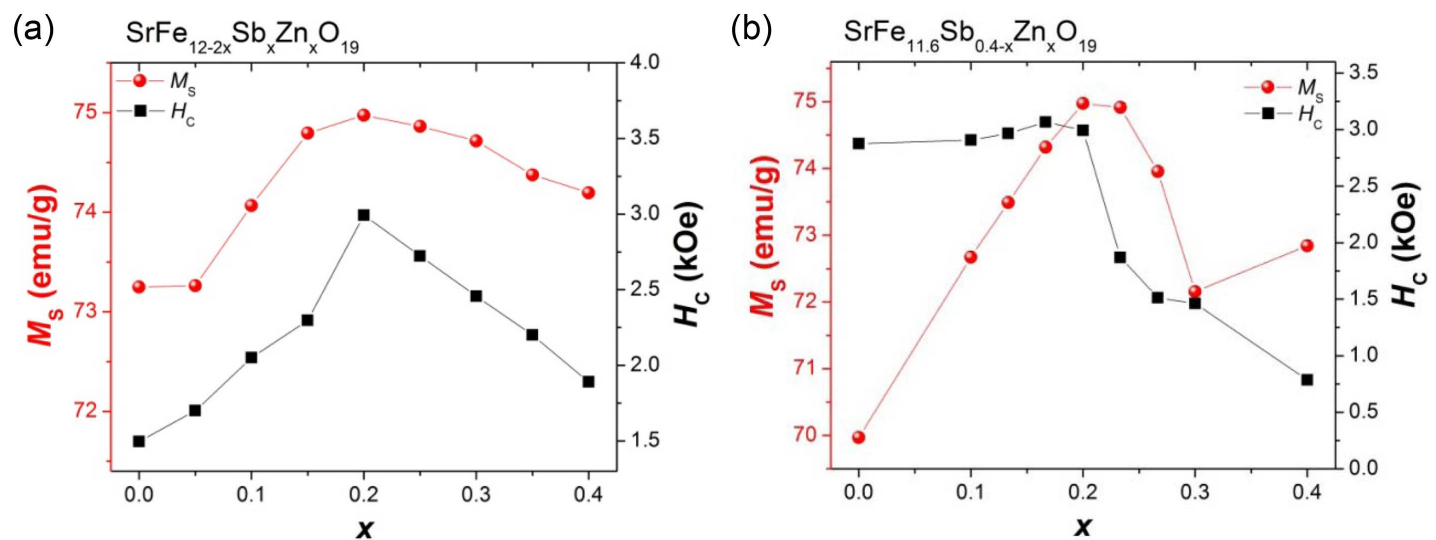

Fig. 2. (Color online) Dependences saturation magnetization $\left(M_{\mathrm{S}}\right)$ and coercive force $\left(H_{\mathrm{C}}\right)$ from substitution amount $x$ for (a) SrFe $e_{12}$ ${ }_{2 \mathrm{x}} \mathrm{Sb}_{\mathrm{x}} \mathrm{Zn}_{\mathrm{x}} \mathrm{O}_{19}$ and (b) $\mathrm{SrFe}_{11.6} \mathrm{Sb}_{0.4-\mathrm{x}} \mathrm{Zn}_{\mathrm{x}} \mathrm{O}_{19}$ nominal compositions.
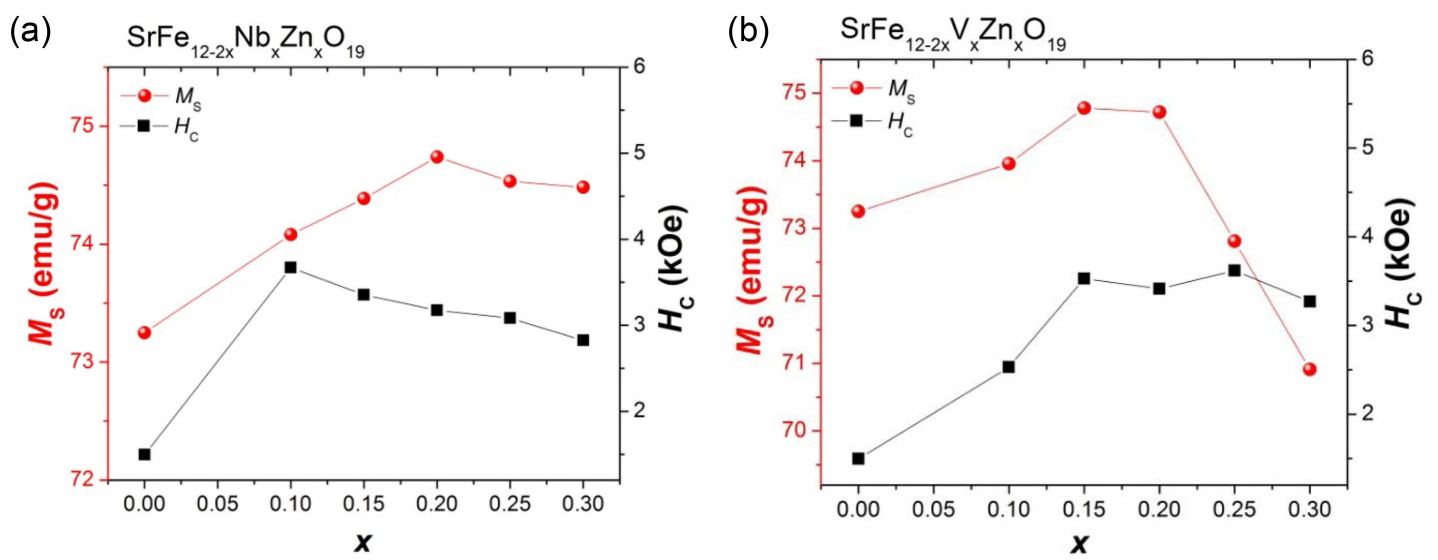

Fig. 3. (Color online) Dependences saturation magnetization $\left(M_{\mathrm{S}}\right)$ and coercive force $\left(H_{\mathrm{C}}\right)$ from substitution amount $x$ for (a) $\mathrm{SrFe}_{12-2 \mathrm{x}} \mathrm{Nb}_{\mathrm{x}} \mathrm{Zn}_{\mathrm{x}} \mathrm{O}_{19}$ and (b) $\mathrm{SrFe}_{12-2 \mathrm{x}} \mathrm{V}_{\mathrm{x}} \mathrm{Zn}_{\mathrm{x}} \mathrm{O}_{19}$ nominal compositions.

Table 3. Comparison of maximal $M_{\mathrm{S}}$ values obtained for MZn substituted hexaferrites in the present work and literature data. For literature data $M_{\mathrm{S}}$ values were estimated from corresponding graphs.

\begin{tabular}{cccc}
\hline \hline M element & M:Zn & $M_{\mathrm{S}}$, emu/g & Reference \\
\hline \multirow{2}{*}{$\mathrm{Sb}$} & $1: 1$ & 75.0 & Present work \\
& $1: 2$ & 61.0 & {$[10]$} \\
\hline \multirow{2}{*}{$\mathrm{V}$} & $1: 1$ & 74.8 & Present work \\
& $1: 2$ & 55.5 & {$[10]$} \\
\hline \multirow{3}{*}{$\mathrm{Nb}$} & $1: 1$ & 74.7 & Present work \\
& $1: 2$ & 65 & {$[9]$} \\
& $1: 2$ & 65 & {$[7]$} \\
& $1: 2.3$ & 73 & {$[8]$} \\
\hline
\end{tabular}

hexaferrites. Decrease in $M_{\mathrm{S}}$ for $x \geq 0.25$ may be related with a formation of $\alpha-\mathrm{Fe}_{2} \mathrm{O}_{3}$ impurity phase in these samples (see Fig. S1e in Supporting Information).

In order to confirm both a hypothesis regarding mixed oxidation state of $\mathrm{M}$ elements in hexaferrite structure and a mechanism of the increase in $M_{\mathrm{S}}$ with substitution, further studies are necessary. However, the effect of $\mathrm{M}-\mathrm{Zn}$ substitution can be calculated from a simple model. In the assumption of as below:

1. $\mathrm{Zn}$ substitutes only $4 \mathrm{f}_{1}$ position for $\mathrm{Fe}$;

2. Element $M$ substitutes one of nine (per formula unit) octahedral positions $\left(4 \mathrm{f}_{2}, 12 \mathrm{k}\right.$ and $\left.2 \mathrm{a}\right)$ without any preferences.

Then the $M_{\mathrm{S}}$ of a M-Zn substituted hexaferrite can be calculated from a formula:

$$
\begin{aligned}
& M_{S}^{M-Z n}=M_{S}^{\text {pure }} \cdot \frac{S_{0}^{M-Z n}}{S_{0}^{\text {pure }}}= \\
& M_{S}^{\text {pure }} \cdot \frac{-2\left(1-\frac{x}{2}\right)-2\left(1-\frac{x}{9}\right)+6\left(1-\frac{x}{9}\right)+1\left(1-\frac{x}{9}\right)+1}{4} \\
& =M_{S}^{\text {pure }} \cdot\left(1+\frac{1}{9}\right)
\end{aligned}
$$


Table 4. Occupancy of $\mathrm{Fe}^{3+}$ positions in hexaferrite structure for model calculation of $M_{\mathrm{S}}$ in a case of M-Zn substitution.

\begin{tabular}{|c|c|c|c|c|c|}
\hline $\begin{array}{c}\mathrm{Fe}^{+3} \text { positions and } \\
\text { spin direction }\end{array}$ & $4 \mathrm{f}_{1} \downarrow$ & $4 \mathrm{f}_{2} \downarrow$ & $12 \mathrm{k} \uparrow$ & $2 \mathrm{a} \uparrow$ & $2 \mathrm{~b} \uparrow$ \\
\hline Occupancy & $2 \times(1-x / 2)$ & $2 \times(1-x / 9)$ & $6 \times(1-x / 9)$ & $1 \times(1-x / 9)$ & 1 \\
\hline
\end{tabular}

where $M_{S}^{M-Z n}$ is the saturation magnetization of a M-Zn substituted hexaferrite, the $M_{S}^{\text {pure }}$ is the saturation magnetization of a pure hexaferrite, the $S_{0}^{M-Z n}$ is the spin per formula unit of a $\mathrm{M}-\mathrm{Zn}$ substituted hexaferrite at $0 \mathrm{~K}$ (Table 4 ), the $S_{0}^{\text {pure }}$ is the spin per formula unit of a pure hexaferrite at $0 \mathrm{~K}$, and $x$ is the amount of substitution.

Thus, according to above formula the $M_{\mathrm{S}}$ of the substituted hexaferrite with $x=0.2$ is estimated to be $\sim 2.2 \%$ higher than the $M_{\mathrm{S}}$ of pure hexaferrite. We experimentally observed $2.5 \%$ and $0.9 \%$ increase in $M_{\mathrm{S}}$ for $\mathrm{M}-\mathrm{Zn}$ substituted hexaferrites compared to pristine strontium hexaferrite prepared in the present work and monocrystal of strontium hexaferrite [19], respectively.

SEM images are shown in Fig. 4. The average grain size was measured from the images for M-Zn substituted strontium hexaferrite samples with highest $M_{\mathrm{S}}$ and pure strontium hexaferrite. It has been reported that a mean particle size of a substituted hexaferrite is either around or higher than a monodomain size of $M$-type hexaferrites $(\sim 0.4-0.6 \mu \mathrm{m})$ [20-22]. Thus, a significant portion of particles shows a size larger than a monodomain. This leads to reduction in coercive field of powders (3.0-3.5 $\mathrm{kOe}$ ) in comparison with its maximum value of sub-
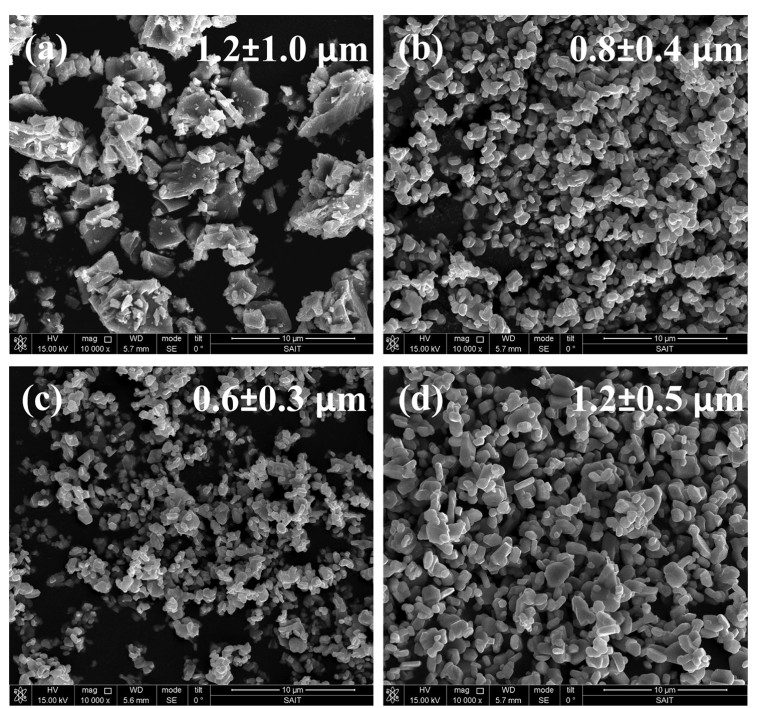

Fig. 4. SEM images for (a) non-substituted strontium hexaferrite sample and substituted strontium hexaferrite samples with following nominal compositions: (b) $\mathrm{SrFe}_{11.6} \mathrm{Sb}_{0.2} \mathrm{Zn}_{0.2} \mathrm{O}_{19}$, (c) $\mathrm{SrFe}_{11.6} \mathrm{Nb}_{0.2} \mathrm{Zn}_{0.2} \mathrm{O}_{19}$, and (d) $\mathrm{SrFe}_{11.7} \mathrm{~V}_{0.15} \mathrm{Zn}_{0.15} \mathrm{O}_{19}$. All samples were calcined at $T=1,255^{\circ} \mathrm{C}$. micron $\mathrm{SrFe}_{12} \mathrm{O}_{19}$ particles (6.3-7.0 kOe) [23, 24]. Furthermore, coercive field could be reduced with decreasing a magnetocrystalline anisotropy constant due to $\mathrm{Fe}^{3+}$ substitution $[22,25]$.

\section{Conclusion}

$\mathrm{M}-\mathrm{Zn}(\mathrm{M}=\mathrm{Sb}, \mathrm{Nb}$, and $\mathrm{V})$ substituted strontium hexaferrite with nominal composition $\mathrm{SrFe}_{12-2 \mathrm{x}} \mathrm{M}_{\mathrm{x}} \mathrm{Zn}_{\mathrm{x}} \mathrm{O}_{19}$ were successfully prepared by a ceramic method. XRD results showed that powders consist mainly of strontium $M$-type hexaferrite phase with a little amount of impurities. For all $\mathrm{M}-\mathrm{Zn}$ systems the saturation magnetization increases with increasing $x$, reaches a maximum (74.7-75.0 emu/g) with $x=0.15-0.2$, and then decreases with further increasing $x$. We speculated that the enhancement in $M_{\mathrm{S}}$ relates with $\mathrm{Zn}^{2+}$ substitution of $4 \mathrm{f}_{1}$ down-spin $\mathrm{Fe}^{3+}$ sites with a mixed oxidation state of $\mathrm{M}$ element. As far as we know it is the first time when saturation magnetization of the nonrare-earth substituted strontium hexaferrite is higher than saturation magnetization of strontium hexaferrite single crystal.

\section{Acknowledgements}

The authors are grateful to Eun Ji Yang for collecting the SEM images.

\section{References}

[1] J. M. D. Coey, J. Magn. Magn. Mater. 248, 441 (2002).

[2] R. C. Pullar, Prog. Mater. Sci. 57, 1191 (2012).

[3] H. Taguchi, T. Takeishi, K. Suwa, K. Masuzawa, and Y. Minachi, J. Phys. IV France 7, C1-311 (1997).

[4] H. Taguchi, J. Phys. IV France 7, C1-299 (1997).

[5] X. Liu, J. Bai, F. Wei, H. Xu, Z. Yang, S. N. Piramanayagam, S. Takei, A. Morisako, and M. Matsumoto, J. Appl. Phys. 87, 2503 (2000).

[6] S. W. Lee, S. Y. An, I. B. Shim, and C. S. Kim, J. Magn. Magn. Mater. 290, 231 (2005).

[7] O. Kubo and E. Ogawa, J. Magn. Magn. Mater. 134, 376 (1994).

[8] Q. Fang, H. Bao, D. Fang, and J. Wang, J. Appl. Phys. 95, 6360 (2004).

[9] O. Kubo, T. Nomura, T. Ido, and H. Yokoyama, J. Magn. Soc. Jpn. 13, 875 (1989). 
[10] U. Meisen and A. Eiling, IEEE Trans. Magn. 26, 21 (1990).

[11] L. Lutterotti, Nucl. Instrum. Methods Phys. Res. B 268, 334 (2010).

[12] T. B. Massalski, H. Okamoto, P. R. Subramanian, and L. Kacprzak, Binary Alloy Phase Diagrams, 2nd ed., ASM International, Materials Park, OH (1990).

[13] H. Okamoto, Supplemental literature review of binary phase diagrams: Cs-In, Cs-K, Cs-Rb, Eu-In, Ho-Mn, K$\mathrm{Rb}, \mathrm{Li}-\mathrm{Mg}, \mathrm{Mg}-\mathrm{Nd}, \mathrm{Mg}-\mathrm{Zn}, \mathrm{Mn}-\mathrm{Sm}, \mathrm{O}-\mathrm{Sb}$, and Si-Sr, J. Phase Equilib. Diff. 34, 251 (2013).

[14] P. Brahma, S. Banerjee, S. Chakraborty, and D. Chakravorty, J. Appl. Phys. 88, 6526 (2000).

[15] P. Brahma, S. Banerjee, and D. Chakravorty, J. Appl. Phys. 98, 064103 (2005).

[16] R. D. Shannon, Acta Cryst. A 32, 751 (1976).

[17] E. W. Gorter, Philips Res. Rep. 9, 403 (1954).

[18] F. Leccabue, G. Albanese, and O. A. Muzio, J. Appl. Phys. 61, 2600 (1987).

[19] B. T. Shirk and W. R. Buessem, J. Appl. Phys. 40, 1294 (1969).

[20] B. T. Shirk and W. R. Buessem, IEEE Trans. Magn. 7, 659 (1971).

[21] H. Sato and T. Umeda, Mater. Trans. JIM 34, 76 (1993).

[22] K. Haneda and H. Kojima, Jpn. J. Appl. Phys. 12, 355 (1973).

[23] D. D. Zaitsev, S. E. Kushnir, P. E. Kazin, and Yu. D. Tretyakov, M. Jansen, J. Magn. Magn. Mater. 301, 489 (2006).

[24] J. Ding, W. F. Miao, P. G. McCormick, and R. Street, J. Alloys Compd. 281, 32 (1998).

[25] E. C. Stoner and E. P. Wohlfarth, Philos. Trans. A 240, 599 (1948).

\section{Appendix: Supporting Information}

This appendix gives working supporting information.

Table S1. Nominal composition and composition from ICPAES data for $\mathrm{Sb}-\mathrm{Zn}$ substituted strontium hexaferrite ( $\mathrm{Sb}: \mathrm{Zn}$ $=1: 1)$.

\begin{tabular}{ll}
\hline \hline Nominal composition & Composition (ICP-AES) \\
\hline $\mathrm{SrFe}_{11.9} \mathrm{Sb}_{0.05} \mathrm{Zn}_{0.05} \mathrm{O}_{19-\delta}$ & $\mathrm{Sr}_{0.99} \mathrm{Fe}_{11.9} \mathrm{Sb}_{0.05} \mathrm{Zn}_{0.05} \mathrm{O}_{19-\delta}$ \\
$\mathrm{SrFe}_{11.8} \mathrm{Sb}_{0.10} \mathrm{Zn}_{0.10} \mathrm{O}_{19-\delta}$ & $\mathrm{Sr}_{0.98} \mathrm{Fe}_{11.8} \mathrm{Sb}_{0.10} \mathrm{Zn}_{0.10} \mathrm{O}_{19-\delta}$ \\
$\mathrm{SrFe}_{11.7} \mathrm{Sb}_{0.15} \mathrm{Zn}_{0.15} \mathrm{O}_{19-\delta}$ & $\mathrm{Sr}_{0.99} \mathrm{Fe}_{11.7} \mathrm{Sb}_{0.14} \mathrm{Zn}_{0.14} \mathrm{O}_{19-\delta}$ \\
$\mathrm{SrFe}_{11.6} \mathrm{Sb}_{0.20} \mathrm{Zn}_{0.20} \mathrm{O}_{19-\delta}$ & $\mathrm{Sr}_{1.00} \mathrm{Fe}_{11.6} \mathrm{Sb}_{0.19} \mathrm{Zn}_{0.19} \mathrm{O}_{19-\delta}$ \\
$\mathrm{SrFe}_{11.5} \mathrm{Sb}_{0.25} \mathrm{Zn}_{0.25} \mathrm{O}_{19-\delta}$ & $\mathrm{Sr}_{0.99} \mathrm{Fe}_{11.5} \mathrm{Sb}_{0.23} \mathrm{Zn}_{0.23} \mathrm{O}_{19-\delta}$ \\
$\mathrm{SrFe}_{11.4} \mathrm{Sb}_{0.30} \mathrm{Zn}_{0.30} \mathrm{O}_{19-\delta}$ & $\mathrm{Sr}_{0.99} \mathrm{Fe}_{11.4} \mathrm{Sb}_{0.28} \mathrm{Zn}_{0.28} \mathrm{O}_{19-\delta}$ \\
$\mathrm{SrFe}_{11.3} \mathrm{Sb}_{0.35} \mathrm{Zn}_{0.35} \mathrm{O}_{19-\delta}$ & $\mathrm{Sr}_{0.99} \mathrm{Fe}_{11.3} \mathrm{Sb}_{0.32} \mathrm{Zn}_{0.33} \mathrm{O}_{19-\delta}$ \\
$\mathrm{SrFe}_{11.2} \mathrm{Sb}_{0.40} \mathrm{Zn}_{0.40} \mathrm{O}_{19-\delta}$ & $\mathrm{Sr}_{1.00} \mathrm{Fe}_{11.2} \mathrm{Sb}_{0.38} \mathrm{Zn}_{0.38} \mathrm{O}_{19-\delta}$ \\
\hline
\end{tabular}

(a) $\mathrm{SrFe}_{12-2 x} \mathrm{Sb}_{x} \mathrm{Zn}_{x} \mathrm{O}_{19}$

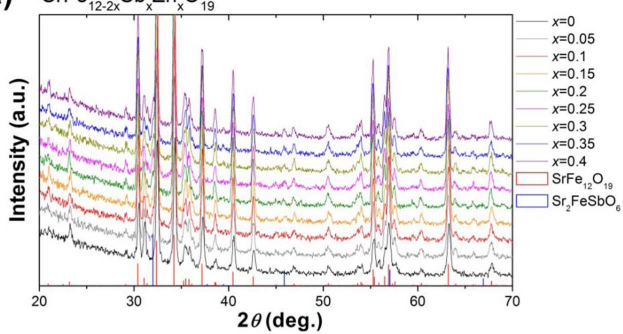

(b) $\mathrm{SrFe}_{11.6} \mathrm{Sb}_{0.4 \times} \times \mathrm{Zn}_{\times} \mathrm{O}_{19}$

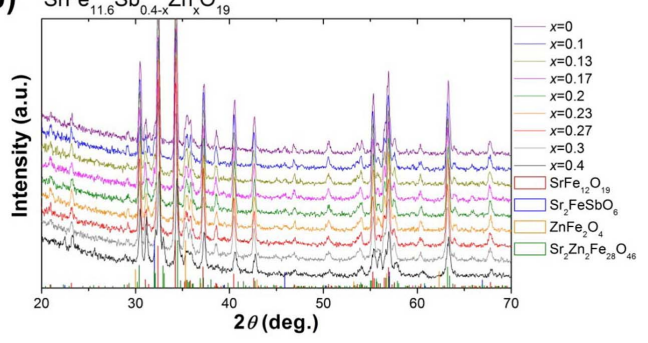

(c) $\mathrm{SrFe}_{12-2 x} \mathrm{Nb}_{x} \mathrm{Zn}_{x} \mathrm{O}_{19}$

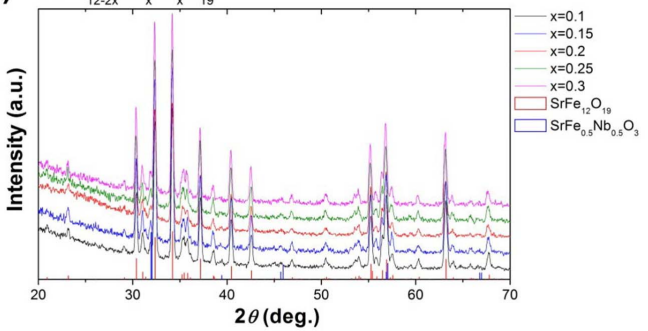

(d) $\mathrm{SrFe}_{12 \cdot 3 \mathrm{x}} \mathrm{Nb}_{\mathrm{x}} \mathrm{Zn}_{2 \mathrm{x}} \mathrm{O}_{19}$

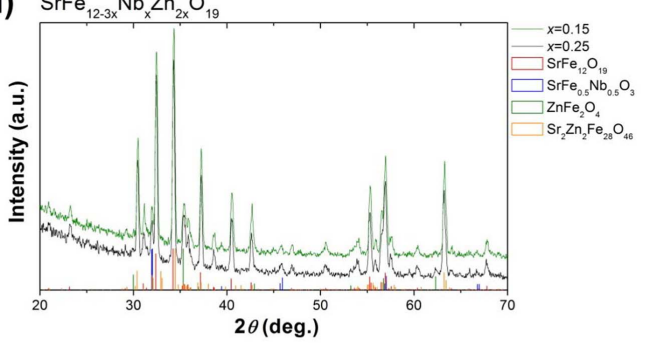

(e) $\mathrm{SrFe}_{12.2 \mathrm{x}} \mathrm{V}_{\mathrm{x}} \mathrm{Zn}_{\mathrm{x}} \mathrm{O}_{19}$

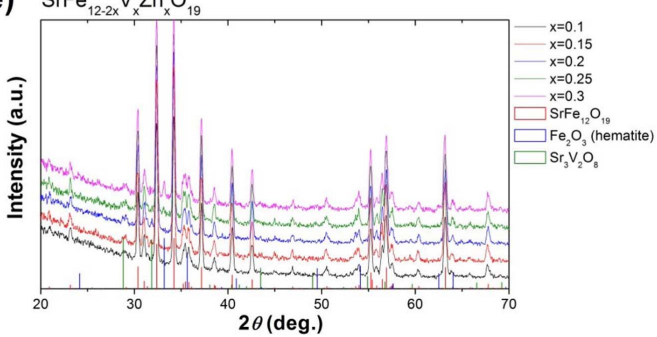

Fig. S1. (Color online) X-ray diffraction patterns for samples with nominal composition: (a) $\mathrm{SrFe}_{12-2 \mathrm{x}} \mathrm{Sb}_{\mathrm{x}} \mathrm{Zn}_{\mathrm{x}} \mathrm{O}_{19}(0 \leq x \leq 0.4)$, (b) $\mathrm{SrFe}_{11.6} \mathrm{Sb}_{0.4-\mathrm{x}} \mathrm{Zn}_{\mathrm{x}} \mathrm{O}_{19}(0 \leq x \leq 0.4)$, (c) $\mathrm{SrFe}_{12-2 \mathrm{x}} \mathrm{Nb}_{\mathrm{x}} \mathrm{Zn}_{\mathrm{x}} \mathrm{O}_{19}$ $(0.1 \leq x \leq 0.3)$, (d) $\mathrm{SrFe}_{12-3 \mathrm{x}} \mathrm{Nb}_{\mathrm{x}} \mathrm{Zn}_{2 \mathrm{x}} \mathrm{O}_{19}(x=0.15 ; 0.25)$, (e) $\mathrm{SrFe}_{12-2 \mathrm{x}} \mathrm{V}_{\mathrm{x}} \mathrm{Zn}_{\mathrm{x}} \mathrm{O}_{19}(0.1 \leq x \leq 0.3)$. Standard $\mathrm{x}$-ray patterns are shown on the corresponding figures as vertical lines (ICSD card numbers: 01-080-1197 ( $\left.\mathrm{SrFe}_{12} \mathrm{O}_{19}\right), 01-087-1732\left(\mathrm{Sr}_{2} \mathrm{FeS}-\right.$ bO $)_{6}$, 01-089-1010 ( $\left.\mathrm{ZnFe}_{2} \mathrm{O}_{4}\right)$, 01-079-0476 ( $\left.\mathrm{Sr}_{2} \mathrm{Zn}_{2} \mathrm{Fe}_{28} \mathrm{O}_{46}\right)$, 01-075-0002 ( $\left.\mathrm{SrFe}_{0.5} \mathrm{Nb}_{0.5} \mathrm{O}_{3}\right)$, 01-081-1844 $\left(\mathrm{Sr}_{3} \mathrm{~V}_{2} \mathrm{O}_{8}\right), 00$ 033-0664 $\left.\left(\alpha-\mathrm{Fe}_{2} \mathrm{O}_{3}\right)\right)$. 
Table S2. Properties of hexaferrite powders: $M_{\mathrm{S}}, H_{\mathrm{C}}$ and grain size.

\begin{tabular}{|c|c|c|c|c|}
\hline Nominal composition & $\mathrm{x}$ & $M_{\mathrm{S}}, \mathrm{emu} / \mathrm{g}^{*}$ & $H_{\mathrm{C}}, \mathrm{kOe}^{*}$ & Grain size, $\mu \mathrm{m}$ \\
\hline $\mathrm{SrFe}_{12} \mathrm{O}_{19}$ & - & 73.2 & 1.50 & $1.2 \pm 1.0$ \\
\hline \multirow{8}{*}{$\mathrm{SrFe}_{12-2 \mathrm{x}} \mathrm{Sb}_{\mathrm{x}} \mathrm{Zn}_{\mathrm{x}} \mathrm{O}_{19}$} & 0.05 & 73.3 & 1.74 & - \\
\hline & 0.10 & 74.1 & 2.05 & $1.0 \pm 0.6$ \\
\hline & 0.15 & 74.8 & 2.30 & - \\
\hline & 0.20 & 75.0 & 2.99 & $0.8 \pm 0.4$ \\
\hline & 0.25 & 74.9 & 2.72 & - \\
\hline & 0.30 & 74.7 & 2.46 & $0.6 \pm 0.3$ \\
\hline & 0.35 & 74.4 & 2.20 & - \\
\hline & 0.40 & 74.2 & 1.89 & $0.6 \pm 0.3$ \\
\hline \multirow{9}{*}{$\mathrm{SrFe}_{11.6} \mathrm{Sb}_{0.4-\mathrm{x}} \mathrm{Zn}_{\mathrm{x}} \mathrm{O}_{19}$} & 0.00 & 70.0 & 2.88 & - \\
\hline & 0.10 & 72.7 & 2.91 & - \\
\hline & 0.13 & 73.5 & 2.97 & - \\
\hline & 0.17 & 74.3 & 3.07 & - \\
\hline & 0.20 & 75.0 & 2.99 & - \\
\hline & 0.23 & 74.9 & 1.87 & - \\
\hline & 0.27 & 74.0 & 1.51 & $1.1 \pm 0.6$ \\
\hline & 0.30 & 72.2 & 1.46 & - \\
\hline & 0.40 & 72.8 & 0.79 & - \\
\hline \multirow{5}{*}{$\mathrm{SrFe}_{12-2 \mathrm{x}} \mathrm{Nb}_{\mathrm{x}} \mathrm{Zn}_{\mathrm{x}} \mathrm{O}_{19}$} & 0.10 & 74.1 & 3.67 & $0.7 \pm 0.3$ \\
\hline & 0.15 & 74.4 & 3.35 & - \\
\hline & 0.20 & 74.7 & 3.17 & $0.6 \pm 0.3$ \\
\hline & 0.25 & 74.5 & 3.08 & - \\
\hline & 0.30 & 74.5 & 2.82 & $0.7 \pm 0.3$ \\
\hline \multirow{2}{*}{$\mathrm{SrFe}_{12-3 \mathrm{x}} \mathrm{Nb}_{\mathrm{x}} \mathrm{Zn}_{2 \mathrm{x}} \mathrm{O}_{19}$} & 0.15 & 72.8 & 2.38 & - \\
\hline & 0.25 & 72.1 & 2.08 & - \\
\hline \multirow{5}{*}{$\mathrm{SrFe}_{12-2 \mathrm{x}} \mathrm{V}_{\mathrm{x}} \mathrm{Zn}_{\mathrm{x}} \mathrm{O}_{19}$} & 0.10 & 74.0 & 2.53 & $1.4 \pm 0.8$ \\
\hline & 0.15 & 74.8 & 3.53 & $1.2 \pm 0.5$ \\
\hline & 0.20 & 74.7 & 3.42 & - \\
\hline & 0.25 & 72.8 & 3.62 & - \\
\hline & 0.30 & 70.9 & 3.27 & - \\
\hline
\end{tabular}

*Accuracy for $M_{\mathrm{S}}$ and $H_{\mathrm{C}}$ values are $\pm 0.1 \mathrm{emu} / \mathrm{g}$ and $\pm 0.05 \mathrm{kOe}$, correspondingly. 